\begin{tabular}{l|l}
\hline Cotaice & e-ISSN: 2655-9404 p-ISSN: 2721-8376 \\
Vol. 3 No. 3, Oktober 2020 & DOI: 10.20473/ntr.v3i3.22837 \\
\hline
\end{tabular}

Article history: Submitted 25 June 2020; Accepted 2 September 2020; Available online 1 October 2020.

\title{
Kedudukan Sita Marital Harta Bersama Dalam Proses Perceraian Bersamaan Dengan Proses Pailit
}

\author{
Oktavia Nadia Sari \\ Oktavia.nadia.sari-2016@fh.unair.ac.id \\ Universitas Airlangga
}

\begin{abstract}
In the bankruptcy of the debtor's property will be confiscated during the general bankruptcy process. General confiscation (Public attachment, gerechtelijk beslag) itself is in the form of confiscation of the entire assets of debtors who enter bankruptcy assets along with those obtained during bankruptcy. Bankruptcy debtors who are bound by marriage will result in the entry of all assets together with the husband and wife to the bankrupt bank, so that the joint assets of the husband and wife lose their right to control and manage the assets. The problems in this research include: 1. Sita Marital Joint Status in the Divorce Process Simultaneously with the Bankrupt Process 2. Settlement of Joint Assets in the Divorce Process When the Married Couple is declared Bankrupt. The research method used is normative juridical by using Conceptual Approach and Statute Approach. The results of this research can be concluded: 1. Sita Marital submitted to be null and void by law contrary to Article 31 of the Bankruptcy Act 2. Responsibility of husband and wife for debt during marriage resulting in spouses must also share responsibility for shared property. Keywords: Public Attachment; Marital Property; Marital Confiscatio; Responsibility.
\end{abstract}

\begin{abstract}
Abstrak
Didalam proses kepailitan terhadap harta debitor akan dilakukan sita umum selama proses pailit berlangsung. Sita Umum (Public attachment, gerechtelijk beslag) sendiri berupa sita keseluruhan harta kekayaan debitor yang masuk harta pailit beserta apa yang diperoleh selama kepailitan. Kepailitan debitor yang terikat perkawinan akan mengakibatkan masuknya seluruh harta bersama suami isteri ke boedel pailit, sehingga terhadap harta bersama tersebut suami isteri kehilangan haknya untuk menguasai dan mengurus harta tersebut. Rumusan Masalah pada penelitian ini meliputi: 1. Kedudukan Sita Marital Harta Bersama dalam Proses Perceraian Bersamaan dengan Proses Pailit 2. Penyelesaian Harta Bersama Dalam Proses Perceraian Bilamana Pasangan Kawin dinyatakan Pailit. Metode Penelitian yang digunakan yuridis normatif dengan menggunakan Pendekatan Konseptual dan Pendekatan Perundang-Undangan. Hasil dari Penelitian ini dapat disimpulkan: 1. Sita Marital yang diajukan menjadi hapus dan batal demi hukum bertentangan dengan Pasal 31 Undang-Undang Kepailitan 2. Tanggung Jawab suami isteri terhadap utang selama perkawinan berakibat pasangannya harus ikut bertanggung jawab juga terhadap harta bersama.

Kata Kunci: Sita Umum; Sita Marital; Harta Bersama; Tanggung Jawab.
\end{abstract}

\section{Pendahuluan}

Copyright $\odot 2020$ Universitas Airlangga

Undang-Undang Nomor 1 Tahun 1974 tentang Perkawinan atau yang selanjutnya disingkat menjadi UU Perkawinan merupakan unifikasi hukum perkawinan yang ada di Indonesia.Undang-Undang ini mengakui kedudukan 
suami atau istri dalam hukum adalah sederajat, sama dan seimbang. Terwujud dari adanya Pasal yang mengatur pengelolaan harta benda selama perkawinan yang dikelola suami istri maupun hak dan kewajiban yang dimiliki oleh suami maupun istri. Namun demikian unifikasi hukum perkawinan tidak menjamin tidak adanya perselisihan yang terjadi dalam hukum perkawinan, Perkawinan sendiri merupakan perbuatan hukum yang mana apabila dilakukan akan menimbulkan akibat hukum oleh keduanya. ${ }^{1}$ Dengan adanya perkawinan akan menimbulkan akibat hukum baik terhadap kedudukan suami istri, harta perkawinan maupun kedudukan anak yang dilahirkan dalam perkawinan tersebut. Akibat perkawinan terhadap Harta benda perkawinan memiliki peranan yang penting dalam kehidupan suami isteri, utamanya apabila terjadi perceraian. ${ }^{2}$ Ketentuan mengenai harta benda kekayaan di dalam UU Perkawinan diatur didalam Bab VII Pasal 35 tentang harta benda dalam perkawinan.

Harta benda perkawinan menurut UU Perkawinan terbagi menjadi dua yakni Harta bersama dan Harta bawaan, UU Perkawinan mengatur mengenai harta benda dalam perkawinan di dalam BAB VII Pasal 35 ayat (1) \& ayat (2). UU Perkawinan tidak mengatur mengenai pertanggungjawaban terhadap utang pribadi maupun utang bersama selama perkawinan, sehingga untuk dapat melihat pertanggungjawaban terhadap utang pribadi maupun utang bersama selama perkawinan perlu melihat peraturan diluar UU Perkawinan. Pada prinsipnya masing-masing suami atau isteri menanggung utang pribadinya masing-masing. ${ }^{3}$

Salah satu masalah yang seringkali muncul adalah adanya perjanjian pinjam-meminjam uang yang dilakukan oleh seseorang yang terikat perkawinan yang sah, tanpa diketahui dan disetujui oleh pasangannya. ${ }^{4}$ Perjanjian pinjammeminjam tersebut berlangsung dalam jangka waktu yang telah ditetapkan meskipun dalam masa perjanjian tersebut perkawinan putus. Sebab dari putusnya

1 Aisela Sata T Putranto, Sita Marital Harta Bersama Yang Diajukan Sebelum Pailit (Program Magister hukum Universitas Airlangga 2017).[1].

2 ibid.[3].

${ }^{3}$ Isis Ikhwansyah, Hukum Kepailitan Analisis Hukum Perselisihan \& Hukum Keluarga Serta Harta Benda Perkawinan (Keni Media 2012).[13].

4 ibid.[5]. 
perkawinan berdasarkan UU Perkawinan ada beberapa yakni Putusnya karena kematian, Perceraian dan Putusan pengadilan.

Dalam hal putusnya perkawinan disebabkan oleh perceraian, biasanya terhadap harta bersama dapat diajukan sita marital selama proses perceraian berlangsung. Terhadap harta bersama yang dilakukan sita marital, tidak menutup kemungkinan terdapat perjanjian utang-piutang yang dilakukan pada masa perkawinan tanpa sepengetahuan pasangannya. Dalam hubungan hukum utangpiutang tersebut pihak yang berutang biasadisebut dengan debitor dan pihak yang memberiutang atau pinjaman disebut kreditor. ${ }^{5}$ Pada praktiknya tidak menutup kemungkinan terhadap debitor memiliki lebih dari seorang kreditor, dengan demikian dalam hal debitor lalai dalam menjalankan tugasnya melunasi utang-utang tersebut, kreditor berhak atas pelunasan utang utangnya tersebut dengan menjual jaminan yang diberikan debitor kepada kreditor pada saat terjadi perjanjian pinjam-meminjam.

Dalam menyelesaikan perselisihan yang terjadi diantara kreditor dan debitor, biasanya kreditor lebih memilih menyelesaikan melalui pengadilan niaga secara kepailitan. Didalam proses kepailitan biasanya terhadap harta debitor akan dilakukan sitaan umum selama proses pailit berlangsung. Sitaan Umum (Public attachment, gerechtelijk beslag) sendiri berupa sita keseluruhan harta kekayaan debitor yang masuk harta pailit beserta apa yang diperoleh selama kepailitan. ${ }^{6}$ Tujuan dengan adanya sitaan umum terhadap harta kekayaan debitor adalah untuk menghentikan aksi perebutan harta pailit oleh para kreditornya. ${ }^{7}$ Namun, Permasalahan muncul manakalapada saat proses kepailitan berlangsung diketahui bahwa sebagian harta kekayaan debitor yang seharusnya menjadi sitaan umum juga telah dilakukan upaya sita akibat dari adanya proses perceraian.

Pertanyaan penelitian ini terfokus pada apakah sita marital harta bersama dalam proses perceraian menjadi gugur ketika pasangan kawin dinyatakan pailit,

5 ibid.

${ }^{6}$ M. Hadi Shubhan, Hukum Kepailitan: Prinsip Norma Dan Praktik Peradilan (Kencana Prenadamedia Group 2009).[163].

${ }^{7}$ ibid. 
dan bagaimana proses penyelesaian harta bersama dalam boedel pailit terkait dipailitkannya suami atau istri.

\section{Metode Penelitian}

Penelitian ini merupakan penelitian hukum dengan beberapa metode pendekatan masalah yang digunakan yakni Pertama, Pendekatan Peraturan Perundang-undangan (Statute Approach); dan Kedua, Pendekatan Konseptual (Conceptual Approach). Pendekatan Peraturan Perundang-undangan (Statute Approach) dilakukan dengan menelaah semua undang-undang dan regulasi yang bersangkutan paut dengan isu hukum yang sedang ditangani. ${ }^{8}$ Lalu Pendekatan Konseptual (Conceptual Approach) dilakukan dengan cara melakukan penelitian terhadap doktrin-doktrin yang telah ada. ${ }^{9}$

\section{Pailitnya Debitor yang Terikat Perkawinan}

Kepailitan pada dasarnya dapat terjadi kepada siapapun yang memenuhi syarat kepailitan yang ada didalam UU Kepailitan Pasal 2 ayat (1) yang mengatur “Debitor yang mempunyai dua atau lebih kreditor dan tidak membayar lunas sedikitnya satu utang yang telah jatuh waktu dan dapat ditagih, dinyatakan pailit dengan putusan Pengadilan baik atas permohonannya sendiri maupun atas permohonan satu atau lebih kreditornya".

Kepailitanjuga dapat terjadi pada orang perorangan yang terikat perkawinan yang sah, bilamana kepailitan terjadi atas permohonan dari debitor dan debitor terikat perkawinan yang sah, hal ini pun juga telah diatur didalam UU Kepailitan Pasal 4 bahwa "permohonan pernyataan pailit yang diajukan oleh debitor yang terikat perkawinan yang sah harus dengan ada persetujuan dari pasangan debiiturnya." Apabila permohonan penyataan pailit yang mengajukan suami maka hal itu harus mendapat persetujuan dari istri begitupun sebaliknya. 2005).[133].

Peter Mahmud Marzuki, Penelitian Hukum Edisi Revisi Cet.12 (Kencana Prenada Media 9 ibid. [135]. 
Persetujuan pasangan diperlukan didalam Pasal 4 dikarenakan UU Kepailitan mengatur bahwa Kepailitan debitor yang terikat perkawinan akan berdampak pula pada pasangannya sesuai dengan UU Kepailitan Pasal 64 ayat (1) yang mengatur "Kepailitan suami atau istri yang kawin dalam suatu persatuan harta, diperlakukan sebagai kepailitan persatuan harta tersebut." sehingga terhadap Pasal tersebut memberi arti tidak peduli suami atau istri yang memiliki utang dan suami atau istri yang diputus pailit, apabila Suami atau istri menikah didalamnya terdapat persatuan harta atau harta bersama dan tidak memiliki perjanjian kawin yang memisahkan harta suami istri maka kepailitan suami meliputi kepailitan istri pula begitupun sebaliknya.

\section{Sita Umum Kepailitan Mengalahkan Sita Eksekusi}

Sejak dikeluarkan Putusan pailit maka demi Hukum harta kekayaan milik debitor akan dibebani sita umum yang menjadi jaminan pembayaran utang-utang debitor kepada para kreditornya, dengan adanya sita umum kepailitan tersebut maka segala sesuatu yang berhubungan dengan harta kekayaan debitor atau harta pailit harus segera dihentikan sementera demi Hukum dari semua transaksi yang ada. ${ }^{10}$ Seandainya sebelum dikeluarkannya putusan pailit telah ada penetapan pengadilan untuk melakukan sita jaminan atas harta pailit debitor maka demi Hukum penetapan pengadilan tersebut terangkat dengan adanya putusan pailit. ${ }^{11}$ Jika eksekusi atau penetapan pengadilan terus dilangsungkan, dengan sendirinya tindakan tersebut menjadi tidak sah dan menjadi batal demi Hukum karena telah bertentangan dengan UU Kepailitan Pasal 31 yang mengatur:

“Putusan pernyataan pailit berakibat bahwa segala penetapan pelaksanaan Pengadilan terhadap setiap bagian dari kekayaan Debitor yang telah dimulai sebelum kepailitan, harus dihentikan seketika dan sejak itu tidak ada suatu putusan yang dapat dilaksanakan termasuk atau juga dengan menyandera Debitor".

Ketentuan pada Pasal 31 UU Kepailitan ini mengenyampingkan atau

\footnotetext{
${ }^{10}$ M. Hadi Shubhan (n 6). Op.Cit.[168].

11 ibid.
} 
merupakan pengecualian terhadap asas dan larangan terhadap sita eksekusi yang telah memiliki daya mengikat, Yahya Harahap dalam bukunya yang berjudul "Ruang Lingkup Permasalahan eksekusi bidang perdata" menjelaskan bahwa daya mengikat yang ada pada sita eksekusi dapat menyingkirkan sita dan eksekusi yang lain dan mengenyampingkan pihak manapun contoh nya jual beli atau penganggunan akan batal demi Hukum jika dilakukan setelah sita eksekusi diletakkan bahkan sita eksekusi pada asasnya melarang sita atau eksekusi atas barang yang sama pada waktu yang bersamaan. ${ }^{12}$

Didalam aturan hukum seringkali dijumpai keadaan seperti konflik antar norma Hukum (Antinomi Hukum), kekosongan Hukum (leemten in het recht) dan adanya norma yang kabur (vage normen) atau norma yang tidak jelas ${ }^{13}$ Pengaturan terhadap sita eksekusi dan sita umum ini merupakan keadaan aturan Hukum yang dikategorikan konflik antar norma terjadi benturan pada pengaturan sita eksekusi dan sita umum didalam kepailitan. Terhadap konflik antar norma yang terjadi pada Penyitaan dalam Kepailitan berdasarkan asas preferensi Hukum sesuai dengan asas Lex Specialis Derogat Legi Generalis Penyitaan dalam proses kepailitan tunduk kepada UU Kepailitan karena didalamnya mengatur khusus penyitaan dalam kepailitan ${ }^{14}$ Terhadap ketentuan sita eksekusi yang hendak atau yang sedang berjalan bilamana debitor diputus pailit maka seketika itu berlakulan Pasal 31 UU Kepailitan, Sita eksekusi yang diatur pada Pasal 31 merupakan aturan khusus yang mana menyingkirkan aturan umum dari sita eksekusi. ${ }^{15}$

\section{Keberlakuan Pasal 31 UU Kepailitan Terhadap Sita Marital}

Dalam UU Kepailitan menyatakan putusan pailit berakibat bahwa segala harta kekayaan milik debitor masuk kedalam harta pailit (boedel pailit), yang dikenal dengan "Sita Umum" (Public attachment, gerechtelijk beslag).

\footnotetext{
12 ibid.[102].

13 Ahmad Rifai, Penemuan Hukum Oleh Hakim Dalam Perspektif Hukum Progresif (Sinar Grafika

14 Aisela Sata T Putranto (n 1). Op.Cit.[54].

${ }^{15}$ M Yahya Harahap, Ruang Lingkup Permasalahan Eksekusi Bidang Perdata (Sinar Grafika 2017).[104].
} 2011).[89]. 
Sita umum ini sendiri merupakan cermin dari adanya kepailitan karena UU Kepailitan menjadikannya sebagai titik tolak sebuah kepailitan hal ini sebagaimana diatur dalam Pasal 1 angka 1 UU Kepailitan, "kepailitan adalah sita umum atas semua kekayaan debitor......" Pengertian kepailitan mengambarkan bahwa kepailitan adalah segala sesuatu menyangkut sita umum.

Pada beberapa kasus kepailitan yang telah terjadi di Indonesia, harta kekayaan debitor pailit dapat dilakukan sita lainnya diluar sita umum sebelum dijatuhi putusan pailit. Terhadap debitor yang terikat perkawinan yang sah kawin dengan persatuan harta maka harta pailit tersebut meliputi harta bersama dalam perkawinan tersebut yang mana harta bersama itu masuk kedalam boedel pailit untuk selanjutnya penjualan nya dibagi atas utang-utang debitor kepada kreditornya.

Bilamana terhadap harta bersama debitor pailit telah diletakkan sita marital sebelum debitor dijatuhi putusan pailit untuk penyelesaianya perlu diliat ketentuan yang ada terkait kedua sita tersebut. Ketentuan sita marital harta bersama Berdasar pada Pasal 823 i Rv yang telah dimodifikasi, dengan jatuhnya sita harta bersama atas harta benda, maka menghalangi penyitaan pihak ketiga. Ketentuan ini memiliki prinsip yang sama dengan Pasal $436 \mathrm{Rv}$ yang mengatur tentang sita penyesuaian. ${ }^{16}$

Kepailitan terhadap debitor yang terikat perkawinan yang sah, sesuai dengan Pasal 23 UU Kepailitan mengatur bahwa kepailitan debitor yang menikah dalam persatuan harta meliputi kepailitan pasangannya, yang mana dalam hal suami istreri menikah dengan didalamnya terdapat harta Bersama baik harta Bersama yang lahir karena adanya perjanjian atau lahir dari adanya Undang-undang maka harta Bersama akan masuk kedalam sita umum boedel pailit karena ketentuan pada Pasal ini. Sehingga terhadap harta Bersama tersebut jika sebelum adanya putusan pailit telah diletakkan sita marital maka sita marital akan terangkat dan menjadi sita umum kepailitan yang nantinya harta Bersama tersebut akan

${ }_{16}$ Aisela Sata T Putranto (n 1). Op.Cit.[50]. 
digunakan untuk kepentingan kreditor suami atau isteri yang diputus pailit.

UU Kepailitan pada Pasal 31 mengatur mengenai sita yang berkekuatan eksekutorial yang mana akan gugur dan harus dihentikan seketika sejak adanya putusan pernyataan pailit. "segala penetapan pelaksanaan pengadilan" merupakan istilah dari eksekusi yang mana Jika tergugat tidak menjalankan pemenuhan putusan secara sukarela akan menimbulkan konsekuensi hukum berupa tindakan paksa yang disebut eksekusi.

Terhadap sita marital tujuan utama dari adanya sita marital ini hanya untuk membekukan harta bersama suami-istri melalui penyitaan agar harta tersebut tidak jatuh ke tangan pihak ketiga selama proses perceraian berlangsung atau proses pembagian harta bersama berlangsung ${ }^{17}$ sehingga dengan adanya sita marital tersebut menjadikan suami atau istri dilarang memindahkan harta tersebut kepada pihak lain dalam transaksi apapun. ${ }^{18}$ Oleh karena sifat terhadap sita marital ini hanya menyimpan atau membekukan harta bersama, sita marital ini tidak perlu dinyatakan sah dan berharga apabila dikabulkan, dikarenakan pernyataan sah dan berharga itu hanya diberlakukan untuk memperoleh title eksekutorial yang biasanya mengubah status sita jaminan menjadi sita eksekutorial, sehingga putusan dapat dilaksanakan dengan penyerahan atau penjualan barang yang disita. ${ }^{19}$ Karena pada sita marital ini tidak berakhir dengan penyerahan atau penjualan barang (lelang). ${ }^{20}$ Walaupun sita marital tersebut bukanlah untuk menjamin suatu tagihan uang atau penyerahan barang, melainkan menjamin agar barang yang disita tidak dijual.

Pada Pasal 31 UU Kepailitan ayat (2) mengatur "Semua penyitaan yang telah dilakukan menjadi hapus dan jika diperlukan Hakim Pengawas harus memerintahkan pencoretannya." ini menyebutkan semua sita diangkat sejak diucapkannya kepailitan seorang debitor yang mana ketentuan ini lebih baru dan

\footnotetext{
${ }^{17}$ ibid.

18 ibid.

${ }^{19}$ Muhammad Misbahul Munir, Tinjauan Hukum Islam Terhadap Pelaksanaan Sita Jaminan (Conservatoir Beslag) Di Pengadilan Agama Sleman (Program Sarjana Universitas Islam Negeri Sunan Kalijaga Yogyakarta 2009).[22].

20 ibid.
} 
khusus dibandingkan peraturan yang mengatur sita marital. Mengingat didalam kepailitan harta Bersama merupakan konsekuensi Bersama suami istri sehingga jika salah satu diputus pailit, maka tidak ada lagi kepentingan salah satu pihak baik suami atau istri terhadap harta Bersama tersebut.

UU Kepailitan mengatur kepailitan suami/ istri yang terdapat harta bersama (persatuan) didalammya dianggap kepailitan persatuan harta, sehingga tidak peduli siapa yang membuat utang baik suami atau istri tetapi Harta Bersama akan dijadikan pembayaran untuk memenuhi hak hak kreditor debitor pailit, maka terhadap sita marital yang telah diajukan menjadi gugur karena adanya putusan pailit, Sita umum kepailitan mengalahkan kepentingan suami istri terhadap harta Bersama.

\section{Tanggung-Jawab Suami atau Istri terhadap utang yang dibuat selama perkawinan dalam proses perceraian bersamaan dengan proses pailit}

Berdasarkan UU Kepailitan Pasal 23 bilamana debitor yang terikat perkawinan diputus pailit maka meliputi pula pasangan dari debitor pailit yang menikah dalam persatuan harta. Redaksi yang digunakan dalam pasal ini masih menggunakan istilah "Persatuan harta" yang terdapat didalam $B W$, sedangkan bilamana mengacu pada UU Perkawinan tidak menggunakan konsep "persatuan harta" yang ada di dalam BW melainkan Pemisahan harta dengan adanya UU Perkawinan perkawinan otomatis membagi menjadi dua harta yakni harta bersama sebagaimana dimaksud dalam Pasal 35 ayat (1) lalu harta bawaan sebagaimana dimaksud dalam Pasal 35 ayat (2). ${ }^{21}$

Pengaturan dalam kepailitan Pasal 64 yang menyatakan kepailitan suami atau istri yang kawin dalam suatu persatuan harta, diperlakukan sebagai kepailitan persatuan harta tersebut, terhadap ketentuan tersebut bila mengacu pada UU Perkawinan yang menggunakan konsep Pemisahan harta kekayaan bila mana suami dan istri menikah setelah berlakunya UU Perkawinan lalu kemudian

${ }^{21}$ Isis Ikhwansyah (n 3)., Op.Cit.[51] 
dinyatakan pailit oleh pengadilan niaga maka harta yang pailit hanya terbatas pada harta yang bersatu saja yaitu harta bersama, terhadap harta bawaan menjadi terlindungi.

Tanggung jawab suami istri terhadap utang yang dibuat oleh salah satu maupun dibuat bersama-sama didalam UU Kepailitan mengatur perbedaan kedudukan, UU Kepailitan lama (Faillissementsverordening) mengatur kedudukan suami istri yang tidak seimbang dalam pembagian tanggung jawab terhadap utang suami/istri. Pasal 60 ayat (1) mengatur bahwa "untuk kepailitaan suami, istri dapat tampil di muka sebagai kreditor" berbeda dengan kepailitan istri, bila istri pailit maka harta suami ikut bertanggung jawab atas pelunasan utang istri tersebut.

Sejak berlakunya UU Perkawinan menjadikan kedudukan suami dan isteri menjadi seimbang sebagaimana tertuang dalam Pasal 31 ayat (1) UU Perkawinan dan UU Kepailitan, sehingga kedudukan yang tidak seimbang antara tanggung jawab suami istri terhadap utang tersebut menjadi tidak relevan lagi untuk digunakan. Jika konsep harta Bersama dalam UU Perkawinan dikaitkan dengan kepailitan, maka dapat diskemakan dibawah ini akibat hukum pailit bagi pasangannya suami/istri, antara lain: ${ }^{22}$

\begin{tabular}{|c|c|c|c|c|}
\hline No & $\begin{array}{l}\text { Luasnya Harta } \\
\text { Perkawinan }\end{array}$ & $\begin{array}{l}\text { Debitor pailit } \\
\text { (Suami/istri) }\end{array}$ & $\begin{array}{l}\text { Akibat bagi } \\
\text { Pasangannya }\end{array}$ & Luasnya Harta Pailit \\
\hline 1. & $\begin{array}{l}\text { Harta Bersa- } \\
\text { ma dan Harta } \\
\text { Bawaan }\end{array}$ & Pailit & Pailit & $\begin{array}{l}\text { Seluruh harta kekayaan (Harta bawaan+ } \\
\text { Harta bersama) dengan ketentuan : } \\
\text { a. Untuk kepentingan Bersama tanpa } \\
\text { mempedulikan siapa yang melaku- } \\
\text { kannya maka yang menjadi harta } \\
\text { pailit adalah harta bersama. } \\
\text { b. Untuk kepentingan sendiri maka } \\
\text { yang menjadi harta pailit adalah } \\
\text { harta bawaan masing-masing sua- } \\
\text { mi/istri. }\end{array}$ \\
\hline
\end{tabular}

Berbeda dengan konsep $B W$ yang mengakui suatu perkawinan tanpa harus adanya harta Bersama dalam konsepsi UU Perkawinan bahwa setiap perkawinan pasti menyebabkan adanya harta Bersama yang mana harta Bersama ini lahir 
bukan karena adanya perjanjian melainkan lahir dari adanya undang-undang. ${ }^{23}$ Undang-undang Kepailitan menganut konsep harta Bersama dari BW jika dilihat pada Pasal 4 ayat (2); "ketentuan sebagaimana dimaksud pada ayat (1) menjadi tidak berlaku apabila tidak ada persatuan harta".

Menurut Jono dalambukunya yang berjudul “Hukum Kepailitaan” dikatakan bahwa terhadap kreditor yang ingin mengajukan pailit terhadap debitor yang terikat perkawinan yang sah perlu memperhatikan perkawinan tersebut tunduk kepada UU Perkawinan atau $B W$, hal ini menjadi penting untuk mengetahui apa didalamnya terdapat harta Bersama atau tidak serta siapa-siapa saja yang harus dimohonkan pailit. ${ }^{24}$ Perlu melihat tunduknya pada $B W$ atau UU Perkawinan dirasa sangat tidak efisien karena akan menimbulkan dualisme antara keduanya, padahal sesuai dengan Pasal 66 UU Perkawinan mengatakan bahwa pengaturan yang ada pada $B W$ menjadi tidak berlaku sepanjang telah diatur didalam UU Perkawinan.

\section{Harta Bawaan Suami atau Istri Bilamama Harta Bersama Tidak Mencukupi untuk Membayar Utang}

Ketentuan didalam UU Kepailitan pada Pasal 64 ayat (3) pada dasaranya mengatur harta yang tidak termasuk kedalam harta persatuan (harta pribadi / harta bawaan milik suami atau istri) dapat masuk kedalam boedel pailit untuk digunakan kepentingan kreditor dengan syarat hanya dapat digunakan untuk membayar utang pribadi milik debitor pailit. ${ }^{25}$ Sehingga jika mengacu pada ketentuan tersebut maka harta bawaan atau harta pribadi hanya dapat digunakan untuk membayar utang pribadi suami atau istri yang diputus pailit, jika suami diputus pailit maka harta yang masuk kedalam boedel pailit adalah harta Bersama suami istri dan harta bawaan suami, begitupun sebaliknya jika istri pailit harta Bersama suami istri dan harta bawan istri yang dijadikan pembayaran bagi kreditor.

\footnotetext{
${ }^{23}$ Jono, Hukum Kepailitan (Sinar Grafika 2010).[49].

24 ibid.

${ }^{25}$ Isis Ikhwansyah (n 3). Op.Cit.[58].
} 
UU Kepailitan melindungi harta bawaan atau pribadi milik suami istri dari proses kepailitan hal itu diatur didalam pasal 64 ayat (3);

“Dalam hal suami atau istri yang dinyatakan pailit mempunyai benda yang tidak termasuk dalam persatuan harta, maka benda tersebut termasuk harta pailit, akan tetapi hanya dapat digunakan untuk membayar utang pribadi suami atau istri yang dinyatakan pailit".

Menurut Isis Ikhwansyah dkk dalam bukunya "Hukum Kepailitan (Analisis Hukum Perselisihan dan hukum keluarga serta harta benda perkawinan)" mengatakan harta bawaan milik pasanagan debitor pailit dapat digunakan untuk membayar utang suami istri pribadi dengan telah dibuktikan terlebih dahulu apakah pada saat utang tersebut dibuat pasangan debitor pailit mengetaui atau menyetujui adanya utang tersebut, seseorang dianggap mengetahui dan menyetujui bisa secara tertulis yaitu dengan adanya akta, secara lisan maupun secara diam-diam, bila hal tersebut dapat dibuktikan maka walaupun pasangan debitor pailit tidak terlibat dalam perjanjian atau sebagai penjamin, maka harta bawaan pasangan debitor pailit dapat dimasukkan kedalam boedel pailit untuk dijadikan pembayaran utang. ${ }^{26}$

Walaupun harta pribadi hanya dapt digunakan untuk membayar utang pribadi suami istri yang dinyatakan pailit akan tetapi bila pasangan debitor pailit secara sukarela memberikan harta bawaannya atau harta pribadi yang dipunya untuk dijadikan pembayaran utang debitor pailit maka hal tersebut diperbolehkan ${ }^{27}$. Mengingat suami istri dalam menjalani perkawinan tidak menutup kemungkinan utang pribadi yang dimiliki suami atau istri digunakan untuk keperluan Bersama rumah-tangga.

Sehingga terhadap kedudukan harta bawaan pasangan debitor pailit jika harta Bersama tidak mencukupi untuk membayar utang kepada kreditor maka harta bawaan pasangan debitor pailit dapat digunakan untuk melunasi utang tersebut bilamana mendapat persetujuan secara sukarela harta tersebut digunakan untuk pelunasan utang debitor pailit atau juga karena alasan-alasan lain yang mengakibatkan masuknya harta bawaan kedalam boedel pailit.

\footnotetext{
26 ibid. Op.Cit.[58].

27 ibid.[60].
} 


\section{Kesimpulan}

Sita Marital yang diajukan bersamaan dengan proses kepailitan menjadi hapus dan harus dilakukan pencoretan oleh Hakim pengawas bila sita tersebut tetap dilangsungkan maka dianggap tidak sah dan batal demi hukum, karena bertentangan dengan Pasal 31 UU Kepailitan. Sejak putusan pailit jatuh kepada debitor yang terikat perkawinan maka harta bersama masuk kedalam boedel pailit, karena Putusan pailit berlaku bagi Pasangan debitor pailit mengikat Harta Bersama dan tidak ada lagi kepentingan salah satu pihak baik suami atau istri terhadap harta Bersama tersebut.

Tanggung jawab suami atau istri terhadap utang yang dibuat selama perkawinan yang didalamnya terdapat harta Bersama berakibat pasangannya harus ikut bertanggung jawab juga terbatas pada harta Bersama, Karena setiap perbuatan hukum yang akan membawa akibat terhadap harta Bersama maka suami istri harus sama-sama dilibatkan (hukumnya memaksa) kecuali dapat dibuktikan pada waktu membuat perjanjian utang piutang pasangan debitor pailit tidak mengetahui sama sekali sesuai dengan Pasal 36 ayat (2) dan hasil pinjaman digunakan untuk kepentingan pribadi maka harta Bersama bagian pasangannya bisa dipertahankan. Namun bila pasangan debitor pailit mengetahui secara jelas atau secara diam-diam walaupun pasangan debitor pailit tidak terlibat secara langsung, pasangan debitor pailit tetap harus bertanggung jawab sebatas harta Bersama sesuai pasal 23 UU Kepailitan. Harta bawaan pasangan debitor pailit terlindungi oleh hukum akan tetapi dapat masuk kedalam boedel pailit bila Pasangan debitor pailit secara sukarela memberikan harta tersebut guna melunasi utang debitor pailit.

\section{Daftar Bacaan}

\section{Buku}

Ahmad Rifai, Penemuan Hukum Oleh Hakim Dalam Perspektif Hukum Progresif (Sinar Grafika 2011).

Aisela Sata T Putranto, Sita Marital Harta Bersama Yang Diajukan Sebelum Pailit 
440 | Oktavia Nadia: Kedudukan Sita Marital...

(Program Magister hukum Universitas Airlangga 2017).

Isis Ikhwansyah, Hukum Kepailitan Analisis Hukum Perselisihan \& Hukum Keluarga Serta Harta Benda Perkawinan (Keni Media 2012).

Jono, Hukum Kepailitan (Sinar Grafika 2010).

M. Hadi Shubhan, Hukum Kepailitan: Prinsip Norma Dan Praktik Peradilan (Kencana Prenadamedia Group 2009).

M Yahya Harahap, Ruang Lingkup Permasalahan Eksekusi Bidang Perdata (Sinar Grafika 2017).

Muhammad Misbahul Munir, Tinjauan Hukum Islam Terhadap Pelaksanaan Sita Jaminan (Conservatoir Beslag) Di Pengadilan Agama Sleman (Program Sarjana Universitas Islam Negeri Sunan Kalijaga Yogyakarta 2009).

Peter Mahmud Marzuki, Penelitian Hukum Edisi Revisi Cet.12 (Kencana Prenada Media 2005).

How to cite: Oktavia Nadia Sari, 'Kedudukan Sita Marital Harta Bersama Dalam Proses Perceraian Bersamaan Dengan Proses Pailit' (2020) Vol. 3 No. 3 Notaire. 